\title{
Power and Discipline: The Role of Accounting in the Monte di Pietà of Ravenna between 18th and 19th Centuries
}

\author{
Carlotta del Sordo ${ }^{1}$, Massimo Fornasari ${ }^{2} \&$ Rebecca L. Orelli ${ }^{3}$ \\ ${ }^{1}$ Department of Sociology and Law, University of Bologna, Italy \\ ${ }^{2}$ Department of Economics, University of Bologna, Italy \\ ${ }^{3}$ Department of Management, University of Bologna, Italy \\ Correspondence: Rebecca L. Orelli, Department of Management, University of Bologna, via Capo di Lucca 34, \\ 40126 Bologna BO, Italy. E-mail: rebecca.orelli@unibo.it
}

Received: March 26, 2019

doi:10.5539/ijbm.v14n7p93
Accepted: April 26, 2019

Online Published: June 9, 2019

URL: https://doi.org/10.5539/ijbm.v14n7p93

\begin{abstract}
This paper aims to fill a gap in the scant literature on accounting practices in non-Anglo-Saxon countries in underresearched periods by exploring the Monte di Pietà of Ravenna, an Italian non-profit institution. The research draws upon original $18^{\text {th }}$ and $19^{\text {th }}$ century documents found in the Monte di Pietà of Ravenna and offers an internal perspective of the development of accounting technology before and after an 'intacco' episode, thus attempting to shed light on the significance of accounting in that context. The originality of the Ravenna episode, compared to other similar ones experienced by Monti, consists in its extension over time and in its recurrence by three generations of administrators linked by kinship bonds, who systematically damaged the Monte between 1797 and 1837. The new form of control of the Monte's activities after the "intacco" based on accounting technologies, and realised a new relation between power and knowledge in which accounting was the tool to exercise disciplinary power, thus making people more governable. Accounting technologies relied upon a more articulated financial statement that included the institute's transactions and events.
\end{abstract}

Keywords: power, discipline, accounting, Monte di Pietà, accounting

\section{Introduction}

Accounting influences and is influenced by organizations in which it acts upon, and for this reason accounting can be viewed as a social and institutional practice (Hopwood \& Miller, 1994; Armstrong, 2015). In this respect, Hopwood (2000) advocates the need to understand financial accounting practices beyond the analysis of financial report structures calls for studies that couple the social and institutional features of accounting in the field of accounting history. Researchers have conducted investigations and analyses of how accounting interacts with its social environment; this reflects a perspective in which accounting is no longer seen as only a technical practice reflecting its environment, but also as a social practice that both mirrors and determines its environment (Gomes, 2008; Gomes et al., 2011; Parker, 2015). As indicated by Miller (1994, p. 20), there is a need "to move beyond the boundaries of the organization and examine the social and institutional practice of accounting" in order to "to understand fully how particular ways of accounting have emerged, and why such significance is accorded to them".

The use of the theoretical perspective of accounting as a social practice inspired several studies regarding the history of accounting in "everyday settings involving various social, religious and other not-for-profit institutions" (Carnegie \& Napier, 2012, 336). Although there are several studies of accounting that use a historical perspective, little is known regarding accounting in non-profit organizations (Dobie, 2011), and in religious organizations (Carmona \& Ezzamel, 2006; Bigoni et al., 2013). This paper aims to fill a gap in the scant literature on accounting practices in non-Anglo-Saxon countries in under-researched periods by exploring the Monte di Pietà of Ravenna, an Italian non-profit institution. The study of the Monte offers an internal perspective on the definition of responsibilities and on the development of accounting technology before and after a significant episode of change. Examining this perspective may illuminate the significance of accounting in that context.

This study contributes to the accounting history literature by using a social and institutional framework to analyse accounting in the Monte di Pietà of Ravenna during the $18^{\text {th }}$ and $19^{\text {th }}$ centuries. Specifically, the non-profit is 
investigated here through the concepts of governmentality and disciplinary power (Foucault, 1991), already used by other authors (Sharma et al 2012) within the accounting history field. Some accounting researchers (Miller and Rose 1990; Miller and Napier 1993) have already used these concepts in their analyses, arguing that accounting makes people more knowledgeable, calculable and governable, thus emphasising accounting's non-neutral nature (Miller and O'Leary 1987; Napier 2006).

In the field of historical research, there is a need to pay attention to the contextual factors of the period under investigation (Parker 1999, 18) in order to accurately contextualize the phenomenon locally (Carnegie and Napier 1996, 7). The experience of the Monte can be contextualized starting from the last decades of the 15 th century, when the cities of central and northern Italy were the cradle of an original model of credit organization based on pawnbroker loans issued at modest interest rates. This model was called the Monte di Pietà (Avallone, 2007). The new credit institution was the result of a long lasting and complex theoretical debate on the use of money, which had begun with members of the Franciscan Order in the central centuries of the Middle Ages (Kaye, 2000; Todeschini 2009). Some representatives of the Observant Minors, who had made themselves autonomous from the Franciscan Order at the end of the $14^{\text {th }}$ century, proposed the foundation of the new institute, which aimed to financially support the poorer, but not the poorest (the so-called pauperes pinguiores), by removing the former from the clutches of usurers (Muzzarelli, 2001).

In a period of rapid population growth, which generated increasing tensions in the market for basic needs, thus causing widespread impoverishment, the Monti represented a critical institutional innovation: they were able to respond to concerns of both an economic and moral nature (Fontaine, 2008). By countering the primacy traditionally exercised in consumer credit by the Jewish banks, the Monti aimed to work for the common good of the Christian community (Todeschini, 2016). Hence, for the Monti, the purpose of lending was to rationalize and moderate the consumer credit market by encouraging easier access to the market among the lower middle class. For this reason, the Monti have also been described as a form of 'more socially responsible consumer credit' (van der Wee, 1993).

The creation of the Monti di Pietà significantly impacted the economic culture of the time. It contributed to mitigating the vexata quaestio of the condemnation of usury, which had been constantly reaffirmed by the Roman Church since the early centuries of the Christian era (Tan, 2002; Evangelisti, 2016). The bull Inter multiplices issued in 1510 by Pope Leo X (Giuliano de' Medici), a descendant of a powerful family of Florentine bankers, legitimized the demand for charging interest on loans issued by the Monti, or 'denarino', by arguing that interest payment was necessary for meeting operating activities and managing expenses (Vismara, 2004).

During the early modern age, the number of Monti di Pietà operating in the Italian peninsula ranged between 650 and 700 and were located in both cities and villages, primarily in central and northern Italy, but also in the South (Montanari 1999). The organizations became promoters of civic identity, and, until the end of the eighteenth century, they represented the core of the Italian banking system (Fanfani, 2003; Cipolla, 1993, 125; Barile, 2012; Menning, 1993; Del Sordo et al., 2013, p. 278). Over time, the Monti significantly expanded their functions, collecting deposits, granting loans to towns and state courts, issuing censis (annuities), dispensing dowries to impoverished young women and performing treasury functions on behalf of local charitable institutions (Fornasari, 1993; Menning, 1993; Carboni \& Muzzarelli,2008).

In 1796, the Monti suffered the 'pillage' (spoliazione) led by Napoleon, which consisted of the removal from their coffers, 'by right of conquest', of money and precious pledges, which were then used to finance war expenditures (Varni, 1996). In 1807, by decree, the Monti also lost their administrative autonomy by being gathered together, by decree, into the Napoleonic Charitable Congregations. In this situation of functional and institutional break down, the Monti temporarily ceased to conduct the complex tasks it had carried out in the early modern age. Then, during the age of restoration, the Monti regained their autonomy almost everywhere.

The central role played by the Monti in the Italian banking system over the centuries must also be considered in light of the multiple and recurrent attempts to bend the operations of the Monti to their natural purposes. This is probably the most interesting and unknown part of the Monti's long life. Indeed the strengthening of the managerial role - by members of the patriciate - corresponded to a series of misappropriations and abuses despite the presence of a seemingly solid system of crosscheck lead by both municipality and archbishop following the provision of the Trent Council. City patriciates, urban magistrates and various professionals, particularly managers called massari, involved in the internal administration of the Monti, changed the destination of funds and/or stole huge amounts of money from funds reserved for normal use. 'Intacco del massaro' was the term used by contemporaries to indicate fraudulent actions that were detrimental to the Monti (Ferlito, 2009). The 'intacco' stole resources from secured credit and highlighted a scant capacity to control the activities of those institutions. As has 
been noted, "relaxation of the initial ethical rigor, inadequate supervision, establishment of internal family dynasties, collusion between administrators and staff could cause" heavy financial losses, compromising the functionality of the 'economy of charity' of which the Monti were one of the main pillars (Carboni 2015, 169). Managers could steal by using different techniques, which were more or less sophisticated: from the simple theft of cash to the purloining of the precious pledges provided as collateral and from over-evaluation of the pawns to the prolonged and systematic under-evaluation of the sums returned to the Monti by pledges (Fornasari 2017).

The present research draws upon original $18^{\text {th }}$ and $19^{\text {th }}$ century documents found in the Monte di Pietà of Ravenna and offers an internal perspective of the development of accounting technology before and after an 'intacco' episode, thus attempting to shed light on the significance of accounting in that context. The originality of the Ravenna episode, compared to other similar ones experienced by Monti, consists in its extension over time and in its recurrence by three generations of administrators linked by kinship bonds, who systematically damaged the Monte between 1797 and 1837.

A direct investigation of the Monte di Pietà of Ravenna's accounting records allowed us to contrast assumptions and evidence, and, for this reason, to achieve conclusions that may be of interest to other researchers (Zan 2004, 147).

The paper is structured as follows. The next section introduces the pillars of Foucault's thought about power, knowledge and governmentality to lay the groundwork for a social and institutional analysis of the Monte di Pietà's accounting practices. The third section describes the birth and its development of the Monte di Pietà of Ravenna with special attention to the historical context. The subsequent section analyses the response to the 'intacco del massaro' episode among people and accounting practices in order to enable a more responsible government in the Monte di Pietà of Ravenna. The final section aims to explain the changes due to the 'intacco' and its response within Foucault's thought on governmentality and draws some conclusions.

\section{Theoretical Framework}

Foucault's studies on governmentality motivated Peter Miller and Nikolas Rose to generate a body of work that has produced several studies inspired by governmentality across the field of social sciences, particularly in accounting.

Discussing the use of power, Foucault showed that from the $18^{\text {th }}$ century, power mediated finely and often as an invisible hand through practices (Foucault, 1975, 79-112). Embedded and hidden in practices, power can influence people's actions. In this way, people unintentionally collaborate in their "subjection to power itself" (Hoskin and Macve, 1986). Power is not something that a group of people or an institutional process can exercise, and power is not only concerned with oppressing and constraining (Foucault 1980). In fact, the most constraining ways in which power can operate gives rise to new forms of behaviour rather than simply censoring forms of behaviours. Foucault describes how disciplinary practices shifted during the 18th and 19th centuries. For example, acceptable norms of behaviour for people in different fields, such as medicine or psychology (Foucault, 1975), were introduced, thus shaping a peculiar relationship between power and knowledge in the people that could control the understanding of power in order to control people. The docility of the human being involved in a given society was the result of the disciplinary process (Foucault,1975).

Within the power-knowledge relationship, accounting exercises disciplinary power, as the practice is strongly involved in power relations produced in social life (Stewart, 1992). Following Foucault's thought, accounting makes people more knowledgeable, calculable and governable (Burchell et al., 1985; Hoskin \& Macve, 1986, 2000; Miller and O'Leary, 1987; Funez, 2005); this refutes the conception that accounting is a neutral process aimed toward economic rationality (Miller \& O’Leary, 1987; Napier, 2006).

Another notion that has inspired accounting scholars is Foucault's concept of governmentality. Governmentality is "the ensemble formed by the institutions, procedures, analyses and reflections, the calculations and tactics that allow the exercise of this very specific albeit complex form of power, which has as its target population, as its principal form of knowledge political economy, and as its essential technical means apparatuses of security" (Foucault 1991, 102-103). To describe the technology used to exercise power, Foucault defines governmentality as a "type of power called government", arguing that "The tendency which, over a long period and throughout the West, has steadily led towards the pre-eminence over all other forms (sovereignty, discipline, etc.) of this type of power which may be termed government, resulting, on the one hand, in the formation of a whole series of specific governmental apparatuses, and, on the other, in the development of a whole complex of savoirs" (Foucault, 1991, p. 103). Governmentality pervades many institutions and practices in both the state (Neu, 2000; Neu \& Graham, 2006) and firms (Dean, 1999; Boyce \& Davids, 2004). 
Governmentality is particularly visible in the $18^{\text {th }}$ century, when governments started defining their way to act in a changing environment that faced huge increases in expenses due to population growth. Population became the main constituent of the state and, consequently, the object of government, rather than territory. Population is much more than the sum of different individuals; it is "a complex phenomenon" with "a life of its own", which must be mastered according to "specific knowledge and through the use of apparatuses of security" (Foucault 2007, 31-32). Because population became the new object of government, government required knowledge to assert its dominance (Dean 1999). This is why, in the $18^{\text {th }}$ century, it was possible to assist to a deviation from the traditional power of the sovereign, founded on custom, social class and patronage, to "a regime ruled by techniques of government" (Foucault, 1991, p. 101). These techniques of government are institutional regimes, knowledges, practices and procedures "structured, internalised and normalised to exercise power over and through certain sectors of society" (Wyn \& White, 1997, p. 133).

From the $18^{\text {th }}$ century, the exercise of power enacted by "assorted attempts at the calculated administration of diverse aspects of conduct", which are "intrinsically linked to the activities of expertise" increased (Rose \& Miller, 1992, p. 175). Thanks to expertise, a "set of problems" is viewed as "specific to the issue of population" (Foucault, 2007, p. 34; Kelly, 2000, p. 304). The basic principle of modern politics is the constant correlation between individualization and totalization, which informs the "governmentalized" state (Foucault, 1991, p. 103). According to Foucault, there is an interplay between two broad sets of techniques inscribed within the technology of power (McKinlay \& Pezet, 2010, p. 487): disciplinary power that it targeted toward individuals and apparatuses of totalization that target the entire population.

In the field of accounting studies, the link between governmentality and disciplinary power can be found in Latour's (1987) notion of "action at a distance", which is widely employed by scholars (Sargiacomo, 2009; Lai et al., 2012). In that vein, accounting is a mirror that can transfer information from distant places and disparate people to a centre that can direct them (Miller \& Rose, 1990; Miller \& Napier, 1993) and explore the role of experts in fostering governmental policies.

The link between governmentality already offered the opportunity to question the context of Italian non profit sector in the eighteenth-nineteenth century. Grounding on Foucault's concept of governmentality some scholars tried to identify the systematic ties between political discourse, forms of rationality and technologies of government during the first period that Napoleon governed Ferrara in northern Italy (1796-99) (Maran et al., 2014). Other authors examined the role of accounting in the power/control relationship between the Papal State and an eighteenth-nineteenth century Italian University (Madonna et al., 2014) or the Fascist regime and the and an the University of Ferrara (Papi et al. in press) using a Foucauldian episteme of disciplinary power and governmentality. Their work revealed how supervised education gradually became a more refined tool of Christian morality, along with papal control of the institution and its expenses. The present paper is situated in the same area of investigation, the context of Italy in $18^{\text {th }}$ and $19^{\text {th }}$ centuries, and analyses the 'intacco del massaro' episode in the Monte di Pietà of Ravenna and its response within Foucault's thought on governmentality.

\section{Methodology}

Authors recommend that accounting history scholars embrace narrative and interpretational history to conduct their research (Previts et al. 1990a; 1990b). Following this suggestion, the present research employs a narrative feature when describing accounting characteristics and its changes due to the specific need to enable more responsible governance within the Monte di Pietà of Ravenna. Moreover, the current study has an interpretational nature (Parker 2015) when highlighting the relationship between the ways to exercise power and discipline and the use of accounting technology in the Monte.

The present study draws upon original $18^{\text {th }}$ and $19^{\text {th }}$ century documents found mainly in the Monte di Pietà of Ravenna, and the methodology of investigation is based on an archival analysis. The direct investigation of original accounting records allows researchers to test hypotheses against evidences of practice, and, for that reason, findings of studies based on that methodology of investigation may have profound influence on future research (Zan, 2004, p. 147).

The Historical Archives of the Monte di Pietà of Ravenna (henceforth ASMPR) keeps records from 1296 to 1939. Up to now, thanks to the partial preservation of its historical archive, it contains 538 archival units. There are three well- identified thematic groups of documents. The first group includes institutional and administrative acts, such as the Statutes (Capitoli) of 1736, the Decrees of the Presidents (1648-1805) and Administrative Correspondence (1694-1837). The second group concerns the Monte accounting documents that certify management and credit pawn activity. The most important series are the 'Main Ledger said Cash book' (1492-1638), the 'Book and chest of the three keys' (1638-1784), 'Books of census' (1688-1767), 'Inventory' drawn up in 1786, 'Ledgers' 
(1824-1938) and 'Financial statement at year-end' (1862-1938). The third group of documents refers, finally, to the legacy of the Monte and their management and assignments (Note 1). Equally important are the Statutes of the 1614, a copy of which is preserved in the Archbishop's Archive of Ravenna (henceforth AARa). For the reconstruction of the Monte of Ravenna history and, in particular of its 'intacco', we made use of both the administrative acts produced by the executive body and the acts gathered in the most important series of Statutes, Decrees, Disputes and Lawsuits, Protocols and Administrative Correspondence as well as the records regarding the work of the manager (Fornasari and Poli 1994). Among the most significant for our work of these records are the manager's cash book, credit books, balance books, financial statements, administrative books and ledgers. In both cases, the documentation starts in the 17th century and extends to the 19th.

\section{The Origins, Activities and Structure of the Monte di Pietà of Ravenna}

Considering the economic relevance of the Monte of Ravenna at the time of the 'intacco', it is important to note that from its foundation the Monte's economic power consistently increased. For this reason we first outline the main events of this organization from its foundation until the beginning of the 'intacco'.

The Monte di Pietà of Ravenna was created during the first wave of foundations of the Monti, which began in Italy in the 1460s and ended in the 1520s (see Figure 1 for the geographical location of the Monte of Ravenna). The idea of establishing a Monte in Ravenna had matured already in 1488, when Bernardino da Feltre preached in the city. On that occasion, the local government bodies pledged to provide a large part of the start-up capital necessary for the new institute. However, the local government bodies had to face the hostility of Venice, and only after the passage of Ravenna to the Serenissima in 1441, the position of the latter consolidated through the systematic renewal of agreements in favour of a single Jewish lending bank (Fornasari 1992). The goal to create a new Monte was only postponed, as in 1492 the Monte of Ravenna was able to begin its activities. Besides its institutional mission - the issue of credit against collateral to the poorest strata of a rapidly growing urban population - the Monte began to accept deposits of money and valuables, to provide dowries for 'poor spinsters' and to ensure large financial support to the municipality. The jurisdictional disputes between urban patricians and episcopal authority gave rise to the dispositions of the Council of Trent (1545-1563), which decided that the local archbishop had to assume the accountancy supervision of the Monti (Fornasari 1993, 178-179).

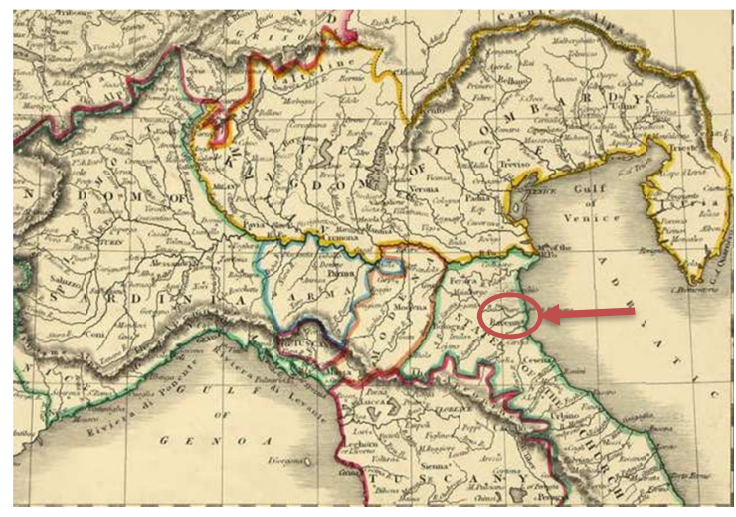

Figure 1. Monte di Pietà of Ravenna (under the State of the Church in 1820)

In order to improve the Monte of Ravenna's activities, the city's government approved in 1614 a partial reform of its original Statutes, which reinforced the operational role of the manager, or 'massaro", of the Monte. With a balance of 60,000 lire in the mid-1580s, the Monte of Ravenna, together with that of Rimini, was the most capitalized among the sixteen Monti in the Romagna region (Fornasari, 1992). However, in the 1630s, the abuses drained large sums of the Monte's funds, which for the first time experienced the 'intacco del Massaro'. This revealed administrative malpractices and reckless self-financing among members of the patriciate: the managers were obliged to repay the ill-gotten gains but with large delays and low interest rates. The measures taken to remedy this state of affairs enabled the resumption of lending operations, which expanded further in the $17^{\text {th }}$ century. The further revision of the Statutes, due to the 'intacco', during 1736 defined new rules regarding the governance structure (Note 2) and showed a growing tension between the local nobility and the archbishop of Ravenna concerning the destination of residues (Fornasari, 1992).

In 1781, the Ravenna's Monte reported a business volume amounting to 50,711 Roman scudi, as shown in Table 1. A few years later, in 1785, a second balance sheet, drawn up after the pastoral visit to the Monte by the new 
Archbishop, Antonio Codronchi, confirmed the institute's solidity but at the same time clarified a number of critical issues (ASMPR 1785: cc.62-63, see again Table 2). The first of them was scant liquidity caused by the extraordinary growth of pawn loans, which had been due to the destabilizing effects of the liberalization of the grain trade on consumers and the excise regime decided by Pope Pius VI in 1786. The Presidents sought to respond to the progressive depletion of cash by increasing the interest (denarino) on loans and reducing pawns by half (Baravelli, 1996).

Table 1. Financial statement of the Monte in 1781 and 1785 (values in Roman scudi)

\begin{tabular}{lll}
\hline Year & 1781 & 1785 \\
\hline Accounts: & & 5,336 \\
Money committed to pledges & 19,380 & 33,054 \\
Capital annuities & 21,871 & 6,687 \\
Money managed by the managers & 8,863 & 824 \\
Sundry credits & 595 & 415 \\
Real estate* & & 3192 \\
Total & 450 & 49,510 \\
\hline
\end{tabular}

Source: ASMPR 1786: cc. 62-63.

With the advance of the French army on the Italian peninsula, the financial difficulties of the Monte paradoxically stemmed from an increase in lending to the poorest sections of the population as well as to the aristocratic, artisanal and mercantile classes, as exemplified by the large amount of jewels and gold and silver objects among the pledges received. Although devastated by the 'Napoleonic pillage', which refers to the 1796 seizure of funds from the Monte of Ravenna by Napoleonic forces, the money kept on hand and in valuable pledges (in this case for a figure equal to almost 34,000 scudi) did not prevent the rapid resumption of the Monte's activities. This was urged by Archbishop Codronchi, who denounced the growth of 'beggars ... for the total extinction of the Monte's (ASMPR 1796) and it was supported by the Council of the Elders, which was also aware of the institute's importance for social security in the city. The raising of money promoted by the municipality and the broad autonomy granted by the French conqueror to the new local oligarchy of money and land, the appropriators of ecclesiastical property, enabled the institute to resume its activities in 1797. Apparently, the Monte re-entered the complex and delicate interplay among the local authorities.

This is the context in which, at the end of the 18th century, the most important case of 'intacco del massaro' took place and gave rise, for the first time, to a different way of exercising power over the other people involved in the management of the Monte di Pietà of Ravenna -- accounting.

\section{Governmentality in the Monte di Pietà of Ravenna}

Among the many cases of 'intacco del massaro' that involved the Italian Monti, the one which concerned the Monte di Pietà of Ravenna between the 18 th and $19^{\text {th }}$ centuries was at the same time the most sensational and exemplary. In effect, its role was significantly weakened by the frauds of three successive stewards of the Monti between 1797 and 1837: Vincenzo, Girolamo and Antonio Dalla Torre. The three managers represented 'a dynasty of massari' tied by kinship, which blatantly and with impunity despoiled the institute of substantial resources in a second 'pillage' after the one by Napoleon Bonaparte (Fornasari 2017; Baravelli 1996; Troilo 2017).

\subsection{People and Accounting in the Monte's Statutes before the 'Intacco'}

The Statutes of 1614 (Capitoli) provided that the Grand Council should elect six Presidents (Presidenti), four nobles and two citizens to act as the administrators of the Monte and some Officials (Ufficiali) to act as employees. Among them, the figure of Massaro (Manager) was responsible in front of the Presidents for the functioning of the institute. In subordinate positions to the manager were a Notary (Notaro), who acted as secretary, and two Assessors (Stimatori), a Tailor and a Goldsmith, who respectively conducted appraisal of pledges consisting of cloths and precious metals (AARa 1614: 6-9).

The Presidents remained in office for three years, whereas the Manager's assignment was two years and renewable once. The Presidents did not receive "good money but only a spiritual reward promised by our Lord Jesus Christ" (AARa, 1614: 9) to conduct their duties. They were to be men of strong morality to administer the Monte selflessly. 
They were required to rule a good father, overseeing the proper functioning of the institution while preserving the integrity of the institution's heritage and supervising employees, would rule the Monte as it.

According to the 1614 Statutes, the manager had to be chosen in compliance with quality requirements with regard to both moral qualities and professional features; however, professional abilities were often not as important as moral qualities. The Manager had to be "a citizen native in Ravenna, mature for age and leading an exemplary life that is not doing any dishonest or vicious activities. He has to be God-fearing, with good conscience and close to the poor" (AARa 1614: 14). As for the professional requirements, Statutes specified how the Manager should be "able in keeping the accounts as the government of a good family" (AARa, 1614, p. 14).

The figure of the Manager was critical, as he held various functions regarding administration and treasury (depositeria). He determined the organization of the entire credit pawn. His accounting duties included the maintenance of the Cask book (Libro del giro), which detailed the movements of money in the Manager's hand and featured the Book of loans and collections (Transunto di tutti li pegni) and Debtors list (Lista dei debitori).

The Manager could not make any expenditure without the permission of Presidents, who had to authorize any payment mandate. The Presidents then carried out a periodic check on the cash flow, and at the end of each year they also had to produce the Balance sheet of income and expenditure (Bilancio delle entrate e delle uscite), but this was also exerted through the use of specialized professionals, as this function was purely of the accounting nature. The outgoing manager had to compile his Mandate balance sheet (Bilancio di mandato del massariato), which he then passed to his successor, and the Presidents elected two auditors to check the financial management of the previous Manager (AARa, 1614, p. 15).

All these new accounting rules disciplining the moment of changeover between two managers are particularly important because an 'intacco' usually arose when the new manager received, from his predecessor, an amount of pledges granted credit for a certain amount of money (Fornasari, 1993, pp. 178-179).

The cash of the Monte were fully deposited on the orders of Presidents in a chest (cassa) with three keys, two of which were in possession of the Presidents and one of which remained with a prior Elder. All the money that came into the Monte daily following the redemption of pawns and the payment obtained from rents, flowed into the chest. The Presidents left the Manager only that amount of money, which they judged sufficient for the needs of the poor, and that amount could not exceed 200 scudi. Incomes and expenditures were recorded by the Notary in a book that had to stay inside the chest along with the money (Libro della cassa con tre chiavi-Book and chest of the three keys). If the pledger was receiving the pledge, he paid the loan plus the matured 'denarino' (interest) to the cashier. If the pledges were not redeemed within two years by the pledger, the pledges were sold at auction, and the notary compiled the Book of unredeemed pawn (Libro della sorte) and noted all the pledges to be put up for auction (AARa, 1614,pp.10-11).

Managers had several duties and to perform them in an honest and rigorous way, a manager could often feel overwhelmed with intolerable hardships and endless chores. In 1615, the manager Francesco Pignatti denounced the inability to successfully carry out his duties, and for that reason the Presidents granted him an Accounting assistant, or Rincontro. This position had to be occupied by a 'uomo honorato' (honourable man) (AARa 1614: 15)and should not be member of the manager's family. The Rincontro would remain in his office for two years and could be confirmed for two more offices if he showed sufficient diligence. The Ricontro's main accounting tasks were to record daily transactions in the Statement of cash (Conto del denaro) with the sums that the Manager had received and paid. Every 15 days, he had also to record in the Book of the cash re-integration (Libro dell'incontro) and all the receipts (bollettini) with incoming and outgoing amounts (AARa, 1614, pp. 23-24).

In 1736 , the statutes of 1614 were revised in order to provide some new rules related to the re-election of officers. The Manager appointed for two years could be re-elected three more times for a total duration of eight years, after which the archbishop's consent was required for a further extension of the mandate. Once he completed his term, he could not be re-elected until after at least four years (ASMPR, 1736, pp. 6-7). Even for the task of Notaro, which were biannual and could already be renewed once, the revised statutes made it possible to have a renewal depending on a President's decision (ASMPR 1736: 18). This extension of mandates follows a direction of less accountability and an even greater centralization of power in the hands of the Manager and indirectly of the aristocracy, as the presidents were (elected by the Grand Council and then by the patrician class) to vote on the appointment and the renewal of a Manager's office.

Despite the provisions of Statutes, the movement of cash and amounts of money in the Manager's hands escaped the control of Presidents, who were required to periodically perform or to commission the auditors with appropriate cash checks. The Presidents therefore decided to appoint a new figure called Computista (Bookkeeper), with responsibilities designed to simplify and rationalize the management of the institute. He was appointed by the 
Presidents as well and remained in his office for two years, though this term could be extended for another two years.

Some accounting functions were delegated to the Bookkeeper, including the maintenance of Main ledgers (Libro mastro di scrittura doppia del dare e dell'avere), some of which previously belonged to the Manager, such as the Mandate balance sheet (Bilancio di mandato del massariato), when the Manager was confirmed or ceased (ASMPR 1736: 18). Table 2 proposes a synthesis of the President's and Official's accounting duties in accordance with the Statutes of 1614 and subsequent revisions.

Table 2. President's and Official's accounting duties in accordance with the statutes of 1614 and revision in 1736

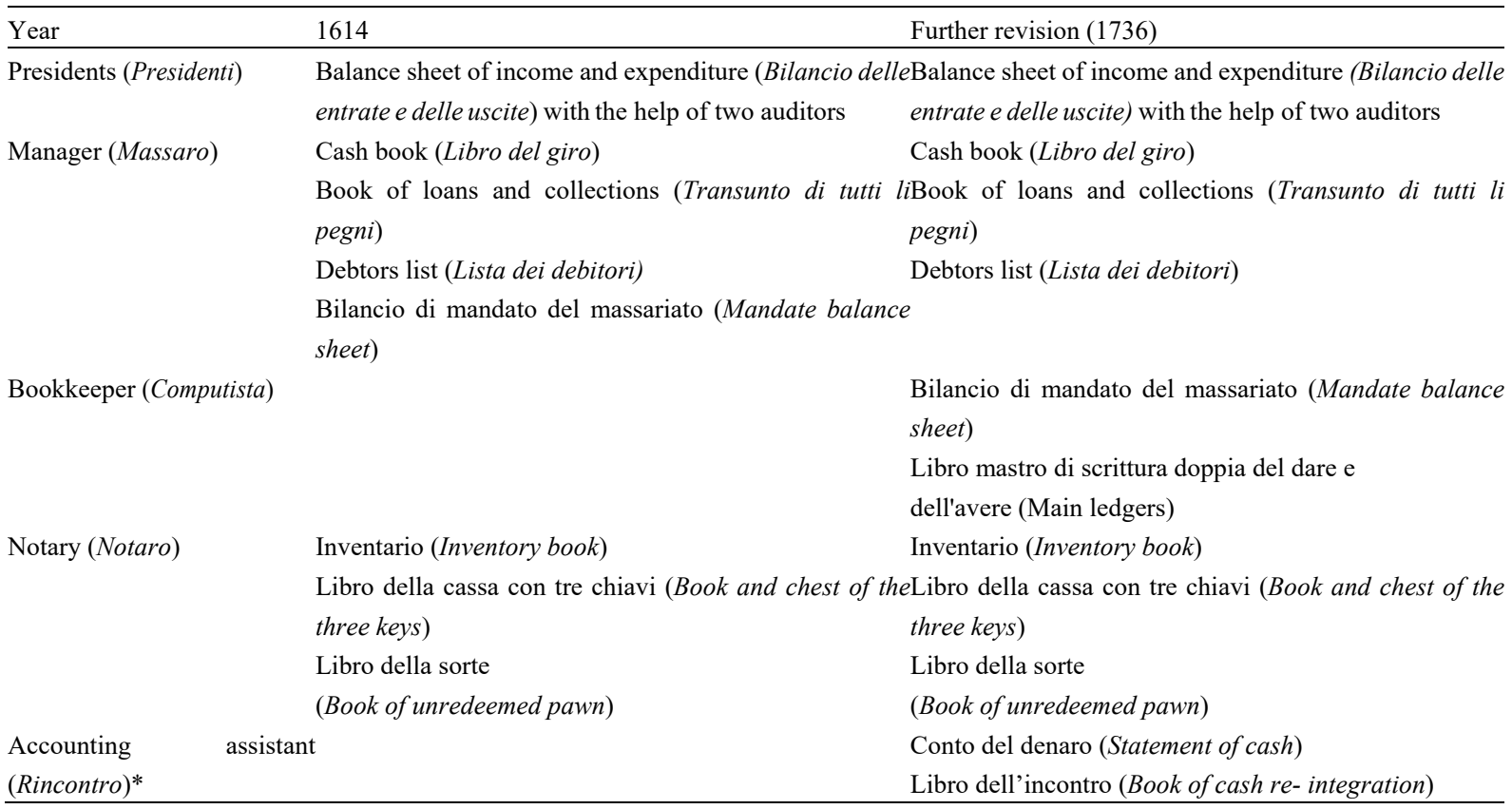

Although the amendments to the Statutes were going in the direction of simplifying and rationalizing activities in order to improve control, confusion, darkness and lack of transparency still characterized the management of the institute. This was made possible because the Accounting assistant, despite the statutory requirements, did not forward the Book of the cash re-integration to the Bookkeeper, who in turn was unable to fill the Main Ledger. This situation created inevitable dysfunctions and obstacles to good practices of management. While increasing irregularities, it decreased the immediacy in the account checks.

Considering the accounting rules, particular emphasis was given to the financial statement. This statement was made up of a single report that reflected the economic result (Sopravanzo di rendita) as a difference between costs (Pesi e spese) and revenues (Rendita). In the same document, assets (Attività), liabilities (Passività) and equity (Sopravanzo d'attivo) were reported at the beginning and the end of the year, using an aggregate form without indicating the single items (Figure 2) (Note 3). In both sections of assets and liabilities, separate columns indicated the total and partial amounts of the various items provided, which were also accompanied by the number of the Ledger page, where the details of its components can be found. The grand total of the amounts in Dare corresponds to the total recorded in Avere, as every financial statement closed in balance. A separation between the Income statement and the Statement of financial position was not envisaged. 


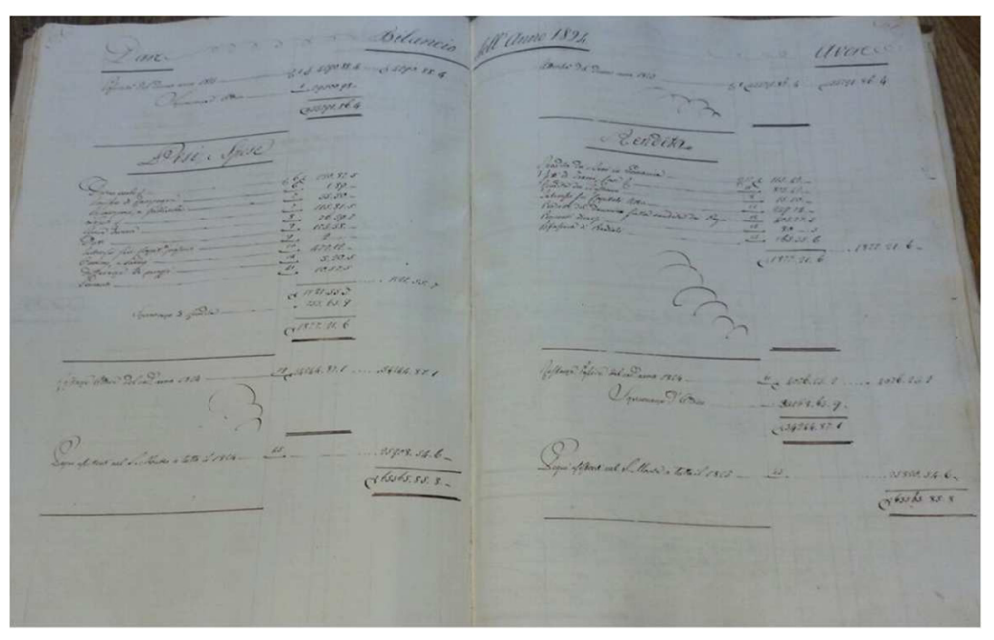

Figure 2. Financial statement (1824)

Fonte: ASMPR Mastri 1824.

The system adopted within the Monte is easy to interpret and allows the reader to focus on some important items such as the economic results of operations (profit or loss of the period) and the total value of the stored goods. However, the frequent change of the name of the various financial statement accounts, and in some cases also the order of registration of them into the schemes, due to the lack of precise drafting rules, does not facilitate comparison of financial statements among several years.

Moreover, the number of financial statement accounts was rather limited (for example in the Dare, there was only an indication of the amount of liabilities for the previous year). The excessive brevity of the financial statement does not allow for adequate analysis of the Monte's financial performance; for example, knowing the main sources of funding, the availability of money and the extent of its assets. Until 1683, an uninterrupted series of positive results (profit of the period) can be related to the Monte's activity.

\subsection{The 'Intacco' episode and Its Response}

During the period from 1796 to 1837, a double 'pillage' took place in the Monte, the one of Napoleon Bonaparte (1796) and the one of the Dalla Torre dynasty (1797-1837). The first pillage took place on 26 June 1796, when the Monte was looted of both money and pledges by Napoleon's troops. The Monte remained closed until 1 November 1797, when it resumed lending activity thanks to the actions of the city's authorities and Antonio Codronchi, archbishop of Ravenna. On that occasion, Vincenzo Dalla Torre was elected as manager. In 1808, his eldest son Girolamo succeeded him until 1824, when Antonio, the son of Vincenzo, Girolamo's younger brother, was appointed and remained in office until 1836. The Dalla Torre family held the position of manager for nearly 40 years, creating a 'dynasty', which provoked predatory practices against the Monte more frequently than in the past. This constituted a second and severe form of 'pillage'.

Considering the long period in which the Dalla Torre family held the position of manager, the suspicion of fraud emerged for the first time in 1815, when Ravenna again became part of the Church State, and the power of controlling Monte's management was returned, and in a superior manner than before, to the archbishop. A dispatch from the apostolic delegate (Note 4) denounced a delay in the recording of accounting operations of the Monte, stating this as the reason that prevented the orderly statement of the firm. The archbishop stated that "thoughtlessly it had been placed in the hands of only one qualified Officer-Massaro- the entire administration of the patrimony of the Monte" with "too daring and independent conduct" (ASMPR 1837: 1). Therefore, external auditors had to perform a thorough audit under the leadership of archbishop Codronchi; it took 15 years to respond to this provision; only in 1830 was a commission established, which was to restore the conditions of autonomy and accounting regularity at the Monte.

In 1830, a careful examination of the accounting books as of November 1807 allowed the archbishop Falconieri, then entrusted to the accountant Angelo Muratori, to ascertain numerous fraud and financial irregularities perpetrated against the Monte by the Dalla Torre's family (ASMPR 1837: 2). The data presented in the financial statements often did not correspond to the real amount of operations. This applied in particular to the amount of the pawns' value deposited in the institute store, which as ascertained at the end of the review, appeared much higher 
than the real amounts. During the period in which the audits took place (from 1833 to 1834), the pawn value dropped from 27,781 to 11,612 scudi (Note 5). After applying the Process of verification of the pawns (Differenza dietro verificazione), it was found that the difference was 16,690 (27,781-11,612 plus denarino) (Figure 3 ), as was highlighted in the financial statement of 1834 (ASMPR 1837: 6). The significant reduction in the value of the pledges coincided with the review of financial statements and revealed the manager's illegal accounting practices.

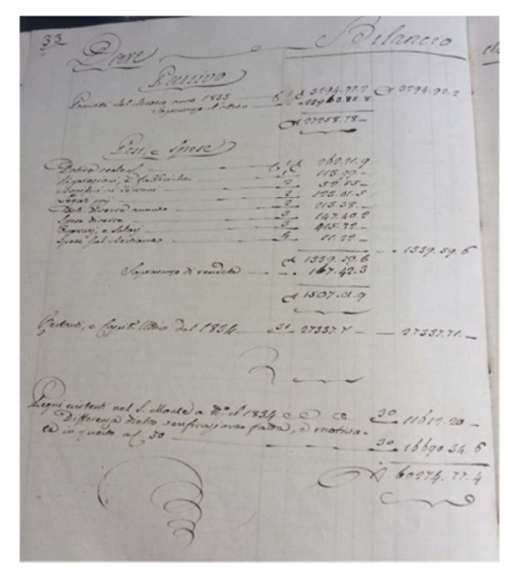

Figure 3. Financial statement after audit - 1834

Fonte: ASMPR, Mastri, 1834.

The accountant Muratori highlighted that the value of the pawns was recorded, rather than the amount of the loan actually disbursed (Note 6). During the Process of verification of the pawns, irregularities were also found in the preparation of the inventory of existing pledges within the warehouses of the Monte. In particular, it lacked 27,000 pledges; this irregularity was attributed to the three Dalla Torre's managers. The total value of the misappropriated pledges was added to the sum of all the non-collected interests, and in 1837 the Dalla Torre's heirs and guarantors were ordered to return the distolto (ASMPR 1837: 7) (amount of stolen money) (Note 7). In the same year, new Statutes were implemented to replace the previous statutes of 1736 , which were annulled by a decree signed by archbishop Falconieri in response to their failure and malfunction.

\subsection{People and Accounting in the Monte's Statutes after the 'Intacco'}

After the 'intacco' episode, in 1836 the archbishop enforced new Statutes (Figure 4). These contained, for the first time, a detailed provision of duties and responsibilities of the Monte's main accounting personnel, as well as a detailed accounting and operational process to guarantee the institution's correct internal functioning (ASMPR 1836) (Note 8) The management of the Monte was entrusted to the Presidents, who were ellected by the archbishop and no longer by the governing bodies of the city, to emphasize more strongly the discontinuity with the recent past. Presidents were requested to control the conduct of the employees on their obligations and on the accounts. The accounting books were to be kept daily and with due regularity. The Presidents were also instructed to ascertain the conservation of the pawns. The new rules required an increased physical presence of the Presidents to fulfil their supervisory functions on the Monte on all the new officials, making a president's role much broader than in the past. The figure of manager disappeared from the statue. The functions that had belonged exclusively to the manager were split to two new officials to guarantee the protection of pawns and the treasury of the Monte respectively: Depositary (Depositario) and Cashier (Cassiere). To understand their role inside the Monte to prevent another possible 'intacco', these personnel should be considered jointly with the Bookkeeper duties. The Bookkeeper (Computista), since the previous Statutes of 1614, was the person to whom duties of an accounting manager and secretary were delegated, such as recording the minutes of the meetings (Congregations) periodically held at the Monte. Following the new Statutes, the archbishop had to directly appoint a Bookkeeper, Depositary and Cashier, and their activities had to take place under the control of all the Presidents, who were selected by the Archbishop (ASMPR 1836: art. 10-14). 


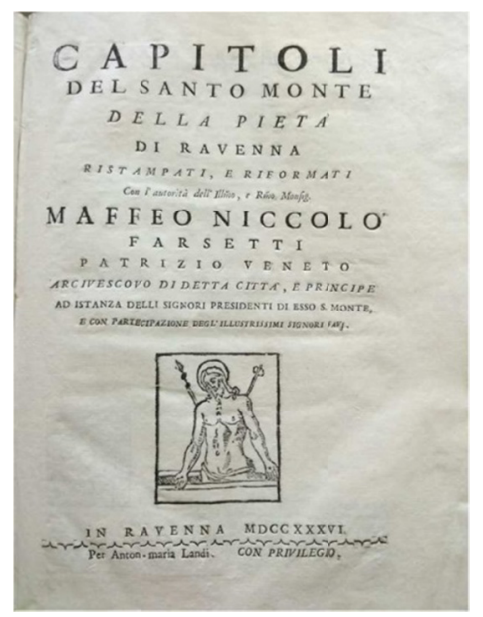

Figure 4. Statutes of 1836 - cover

Fonte: ASMPR, Capitoli del Santo Monte di Pietà (1736).

As a novelty, every year in February in the presence of the archbishop, a General Congregation was held in which all matters of major importance concerning the administration of the institute were addressed. During this General Congregation, the Presidents had to provide an account of the state the Monte's entire administration through the presentation of annual financial statements for the previous year, drawn up by the Bookkeeper. In September, the Bookkeeper also drew up the annual budget for the coming year following the same structure of the financial statement.

Some other accounting duties were delegated to the Bookkeeper, including the maintenance of Main ledgers (Libro mastro di scrittura doppia del dare e dell'avere), included in the Monte's accounting system in accordance with the Statutes of 1614, and the Registers of payment orders and Amounts to be collected (Registri degli ordini di pagamento and Quinternetto di scossa). Moreover, the new Statutes stated that whenever the Archbishop ordered it, the Bookkeeper must proceed to take an inventory of pawns, a task for which he received an additional reward (ASMPR 1837: art.6-7).

To avoid new malpractices, the Statutes ordered that the Cashier must handle the Monte's money after receiving a compulsory order by the Depositary; the two control each other through different accounting records related to the same transaction of the pawns, scriptures containing cross references and elements of repetition. Both the Cashier and Depositary through their accounting records gave rise to two parallel series of Books of loans and collections (Libro dell'impegnato e del riscosso). Their findings were further annotated by a Bookkeeper in the Main Ledger. The Cashier oversaw the amount of the revenues, expenditures and cash related to loans and deposits activities. Given his responsibilities linked with liquidity, he received greater compensation compared to others, but he also had to offer a form of bail for the amounts of cash in his hands. The Cashier was also obliged to keep a Receipt book (Bollettario a madre e figlia) from which he could attain any pledge's receipt, which were in turn recorded in a register called a Cash book (Libro di cassa). He was not allowed to make payments on his own, as he needed regular authorisation issued by a Bookkeeper and signed by Presidents (ASMPR 1836: artt. 39, 40, 42, 79).

The new statutes reframed the Monte's control system. According to these regulations, the Bookkeeper oversaw the periodic controls on the work of both Cashier and Depositary. Particularly, at the end of each month, the Cashier handed a leaflet extracted from the Cash book, and the Depositary delivered the Summary of pawns (Ristretto del giro dei pegni). Then, the Cashier and the Depositary controlled each other throughout the recorded accounting transactions relating to the movement of the pawns; the prescription to take mirror-like registers related to pawnbroking activity on a daily basis allowed a strong form of control. This rule was designed to force people to detect any error and correct it as soon as possible. In Table 3, a summary of the official accounting duties in accordance with the Statutes of 1836 for Bookkeeper, Cashier and Depositary is shown. 
Table 3. Official's accounting duties in accordance with the statutes of 1836

\begin{tabular}{lll}
\hline Computista (Bookkeeper) & Libro mastro di scrittura doppia del dare e dell'avere & Main ledgers \\
\hline & Registri degli ordini di pagamento & \\
& Quinternetto di scossa & Register of payment orders \\
& (Registro delle somme da riscuotere) & Register of amounts to be collected \\
& Bilancio preventivo & \\
& Bilancio consuntivo & Annual budget \\
& Inventario dei pegni & Annual financial statement \\
& Verbali & Pawn's inventory \\
& Bollettario a madre e figlia per gli incassi e le spese & Minutes \\
Cassiere (Cashier) & Dibro di cassa & Cuplicate receipt pad for incomes and expenditures \\
& Libro dell'impegno e del disimpegno & Book of loans and collections \\
Depositario & Libro dell'impegno e del disimpegno & Book of loans and collections \\
(Depositary) & Ristretto del giro dei pegni & Summary of pawns \\
\hline
\end{tabular}

Fonte: ASMPR (1836).

With the implementation of the Statutes of 1837 , the financial statement scheme previously adopted was radically changed. After 40 years of 'intacco', the need for new financial statements was clear; these statements needed to be less synthetic and needed to be organized in such a way that personnel could reconstruct the operations and the overall performance of the Monte by analysing the statements. In accordance with the new rules for the preparation of financial statements, they were made up of two schemes, a Statement of financial position and an Income statement. The first was divided into two sections, the left section headed as Debtors and represented all the activities (such as stocks in warehouses, rustic and urban heritage, cash, pledges), while the right section headed as Creditors and represented the liabilities, including equity and the result of the period. The Income Statement was divided into two sections as well: the left section was headed to the Expenses (Spese), while the right was headed to the Revenues (Rendite). The new structure of financial statements is very similar to the one in use today, and in many cases, it was articulated on two levels as the recorded accounts were divided within sub-headings of creditors' and debtors' names.

The account details were represented in the scriptures of the Ledger, linked with accounts with a reference indicating the corresponding page (Figure 5 parts A and B). Even with this type of linkage, it must be noted that the indication of the accounts in the Financial Statements did not follow a precise order, and often the names of the various accounts changed over time, undermining the transparency of the documents. This practice occurred particularly since 1850, when the Monte appointed a new Bookkeeper. Most likely, the lack of a defined standard on the matter did not help to ensure consistency and comparability of Financial Statements over time. The very last control on the Financial Statements was an external one, executed by the archbishop through one of his personal accountants, who had the power to take any necessary correction and change the documents.

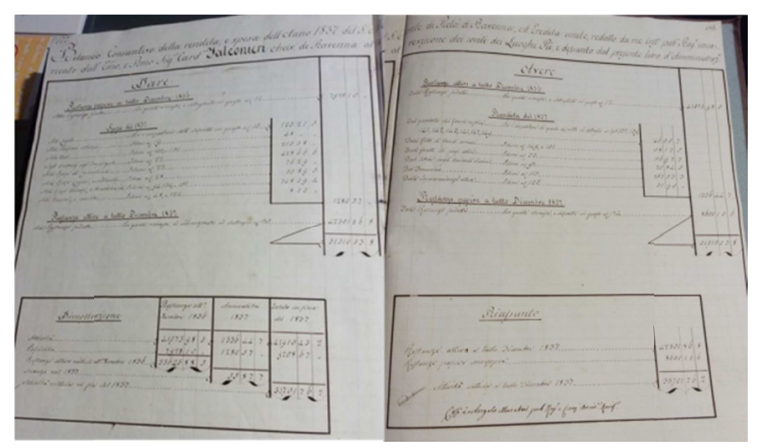

Figure 5 (part A) - Financial statement - 1837 


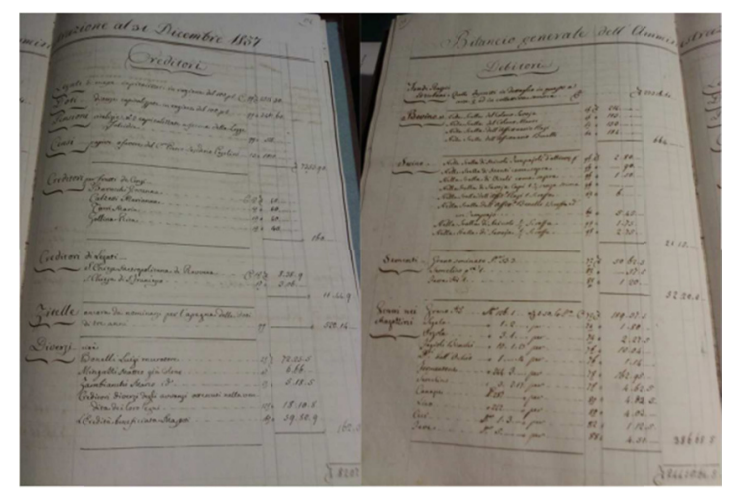

Figure 5. (part B) - Financial statement - 1837

\section{Discussion and Conclusion}

The present study aimed to couple the social and institutional features of accounting in the context of a specific case from the field of accounting history. It draws upon the $18^{\text {th }}$ and $19^{\text {th }}$ century documents of the Monte di Pietà of Ravenna and makes use of the pillars of the Foucault's ideas about power, knowledge and governmentality and conducts an analysis of the people and accounting response to the 'intacco del massaro' episode in order to enable a more responsible government in the Monte di Pietà of Ravenna. In this context, at the end of the 18th century, the most important case of 'intacco del massaro' took place and gave rise, for the first time, to a different way of exercising power on the other people involved in the management of the Monte di Pietà of Ravenna -- specifically, through accounting.

Consistent with Hopwood and Miller (1994), we described accounting in its social and institutional context before and after an episode of change. Following this line, until 1836, before and during the 'intacco del massaro', the power exerted over the Monte personnel derived from the city's patriciates, as it was the Grand Council that elected Presidents, and officials and to establish rules (Statutes) to run the Monte's activities. The Council of Trent offered a first attempt at changing this environment, strengthening the archbishops' power of control over the charities of the Italian peninsula, including the Monti. Nevertheless, the resulting forms of control, though strengthened, were not adequate to preclude the action of 'intacco del massaro'. The described rules tried to operate invisibly through practices according to Foucault (1975). The main reason for this failure is related to the rules, which focused only on the religious virtues or previous professional experiences of the people in charge of the main duties, which were not linked to the activities of expertise. Over time, personnel, particularly Presidents, perceived the described lack of control in the Monte's system and, to try to fix this, implemented revisions of the Statutes. Nonetheless, the Presidents' revisions introduced marginal changes, specifically the instatement of two new officials (Bookkeeper and Accounting Assistant) who had to simplify the Manager's life by taking on some managerial responsibilities. Also, the accounting practices already in use, did not allow people to "collaborate in their subjection to the power itself", consistent with Hoskin and Macve (1986). Particularly, the keeping of accounting records was not conducted according to the rules provided in the Statutes, which led to the exclusion of certain obligations considered unnecessary, repetitive, or, even worse, intended to carry out fraud. These omissions, increasing the autonomy of the manager, made the control on his work long and complex and even impossible.

The 'intacco', whose suspicions emerged in 1815, was officially detected in 1830 during the external audits required by the Archbishop. Significant financial irregularities were found that resulted from Manager conduct made possible by the voluntary absence of aristocracy controls. As the Archbishop did not fail to indicate in a speech during his pastoral visit, putting the entire administration of the Monte's patrimony under the responsibility of a single officer, the manager favoured the 'intacco'. In that moment, the Archbishop gave rise to new forms of behaviour to discipline people. After the 'intacco' episodes, the new acceptable norms of behaviour for people came into force with Statutes of 1837 during the age of Restoration in which the structure of the Grand Council and the expression of the local nobility lost power; at the same time, that power was gained by the Archbishop, who started to nominate both Presidents and Officials. To start, the Archbishop abolished the manager office in the Statutes and introduced new professional officials (Cashier and Depositary) with the aim off forcing them to control each other. Then, the Archbishop established a new form of control of the Monte's activities based on the accounting technologies, realising a new relation between power and knowledge in which accounting was the tool to exercise disciplinary power, thus making people more governable (Miller and O'Leary, 1987; Hoskin and 
Macve, 1986; Napier, 2006). Accounting technologies relied upon a more articulated financial statement that included the institute's transactions and events. The Monte's accounting technologies of government before the 'intacco' relied upon a synthetic Mandate balance sheet, a financial statement covering all the years of the Manager's duties; after the 'intacco' episodes, they depended on a system based on a Financial statement at the year's end and a Budget, both to be prepared annually and on the same exhaustive scheme. In the history of the Monte di Pietà of Ravenna, before reform of the Statutes, the Presidents responsible for administration of the Monte, favoured, or at least did not hinder the Manager's 'intacco'. The Manager experienced huge managerial freedom permitted by the nature of internal rules and accounting technologies, which were not able to act at a distance or to transfer information to the centre that aimed to direct them (Miller and Rose, 1990). It did not help the circumstance that the Dalla Torre's dynasty of managers acted during the Napoleonic age, a time during which the Church lost control over Monti's activities, reducing transparency and enabling illegal practices.

The history of the Monte di Pietà of Ravenna may be of interest for several reasons. We assisted in the introduction of a new regime ruled by techniques of government based on accounting practices and procedures internalized and normalized to exercise power over the Monte. It shows the use of accounting technologies to exercise forms of control on the Massari's practice to detect the possible 'intacco' and to exert disciplinary power in the Monte's daily activity.

\section{References}

Armstrong, P. (2015). The discourse of Michel Foucault: A sociological encounter. Critical Perspectives on Accounting, 27, 29-42. https://doi.org/10.1016/j.cpa.2013.10.009

Avallone, P. (2007). Prestare ai poveri. Il credito su pegno e i Monti di Pietà in area mediterranea (secoli $X V$-XIX). Napoli: Consiglio Nazionale delle Ricerche, Istituto di Studi sulle Società del Mediterraneo

Baravelli, A. (1996). Il Monte di pietà di Ravenna in età napoleonica: mutamento e continuità tra Legazione di Romagna e Regno d'Italia. In Varni A. (Ed.), Per diritto di conquista. Napoleone e la spoliazione dei Monti di pietà di Bologna e Ravenna (pp. 81-140). Bologna: Il Mulino.

Barile, N. L. (2012). Renaissance Monti di Pietà in Modern Scholarship: Themes, Studies, and Historiographic Trends. Renaissance and Reformation, 35(3), 85-114.

Bigoni, M., Deidda Gagliardo, E., \& Funnell, W. (2013). Rethinking the sacred and secular divide: Accounting and accountability practices in the Diocese of Ferrara (1431-1457). Accounting, Auditing \& Accountability Journal, 26(4), 567-594. https://doi.org/10.1108/09513571311327462

Boyce, G., \& Davids, C. (2004). The Dimensions of Governmentality Studies in Accounting: Complementary and Critical Potentials. In Parker, L. and Low, A. M. (Eds.), Collected papers of APIRA 2004. Singapore: Singapore Management University and APIRA.

Burchell, S. A., Clubb, C. B., \& Hopwood, A. G. C. (1985). Accounting in its social context: Towards a history of value added in the United Kingdom. Accounting, Organizations and Society, 10(4), 381-413. https://doi.org/10.1016/0361- 3682(85)90002-9

Carboni, M. (2015). Il credito disciplinato. Il Monte di pietà di Bologna in età barocca. Bologna: Il Mulino.

Carboni, M., \& Muzzarelli, M. G. (2008). I conti dei Monti: teoria e pratica amministrativa nei Monti di Pietà fra Medioevo ed Età Moderna. Venezia: Marsilio

Carmona, S., \& Ezzamel, M. (2006). Accounting and religion: A historical perspective. Accounting History 11(2): 117-127. https://doi.org/10.1177/1032373206063109

Carnegie, G. D., \& Napier, C. J. (1996). Critical and Interpretive Histories: Insights into Accounting's Present and Future Through its Past. Accounting, Auditing and Accountability Journal, 9(3), 7-39. https://doi.org/10.1108/09513579610121956

Carnegie, G. D., \& Napier, C. J. (2012). Accounting's past, present and future: the unifying power of history. $\begin{array}{lllll}\text { Accounting, Auditing \& } \quad \text { Accountability } & \text { Journal, }\end{array}$ https://doi.org/10.1108/09513571211198782

Cipolla, C. M. (1993). Before the Industrial Revolution: European Society and Economy, 1000-1700. London: Routledge.

Dean, M. (1999). Governmentality: Power and Rule in Modern Society. London: Sage.

Del Sordo, C., Fornasari, M., \& Orelli, R. L. (2013). Credit and accounting in early modern Italy: the case of the Monte di Pietà in Bologna. Accounting History Review, 23(3), 273-293. 
https://doi.org/10.1080/21552851.2013.850925

Dobie, A. (2011). A Review of the Granators' Accounts of Durham Cathedral Priory 1294-1433: An Early Example of Process Accounting? Accounting History Review, 21(1), 7-35. https://doi.org/10.1080/21552851.2011.548178

Evangelisti, P. (2016). Il pensiero economico nel Medioevo. Ricchezza, povertà, mercato e moneta. Roma: Carocci

Fanfani, T. (2003). Alle origini della banca. Etica e sviluppo economico. Roma: Bancaria

Ferlito, C. (2009). Il Monte di pietà di Verona e il contesto economico-sociale della città nel secondo Settecento. Venezia: Istituto Veneto di Scienze, Lettere ed Arti.

Fontaine, L. (2008). L'économie morale, Pauvreté, crédit et confiance dans l'Europe préindustrielle. Paris: Gallimard.

Fornasari, M. (1992). Il Monte di Pietà di Ravenna: storia di un'istituzione sociale (1492-1939). In Fornasari, M., Mita, P., and Poli, M. (Eds.), I Cinquecento anni del Monte di Pietà di Ravenna (1492-1992). Bologna: Fondazione del Monte di Bologna e Ravenna

Fornasari, M. (1993). Il "Thesoro" della città. Il Monte di Pietà e l'economia bolognese nei secoli XV e XVI. Bologna: Il Mulino.

Fornasari, M. (2017). "Maltolto" o "distolto"? Governance e frodi nei Monti di pietà delle Legazioni pontificie settentrionali (secoli XVI-XIX). In Righi, L. (Ed.), Storie di frodi. Intacchi, malversazioni e furti nei Monti di pietà e negli istituti caritatevoli tra Medioevo ed Età moderna. Bologna: Il Mulino, pp. 223-238

Fornasari, M., \& Poli, M. (1994). Collectio Actorum. Guida alla Fondazione del Monte e agli archivi storici dei Monti di Pietà di Bologna e Ravenna (sec. XIII-XX). Bologna: Fondazione del Monte di Bologna e Ravenna.

Foucault, M. (1975). Discipline and Punish: the Birth of the Prison. New York: Random House.

Foucault, M. (1980). Power/Knowledge: Selected Interviews and Other Writings, 1972-1977. New York: Pantheon Books.

Foucault, M. (1991). Governmentality. In Burchell, G., Gordon, C., and Miller, P. (Eds.), The Foucault Effect: Studies in Governmentality (pp. 87-104). Chicago, IL: University of Chicago Press.

Foucault, M. (2007). Security, territory, population: lectures at the College de France, 1977-1978. New York: Picador/Palgrave Macmillan.

Funez, D. R. (2005). The interface of disciplinary practices and accounting: the case of the Royal Tobacco Factory of Seville, 1761-1790. Accounting History, 10(1), 71-97. https://doi.org/10.1177/103237320501000104

Gomes, D. (2008). The interplay of conceptions of accounting and schools of thought in accounting history. Accounting History, 13(4), 479-509. https://doi.org/10.1177/1032373208095480

Gomes, D., Carnegie, G. D., \& Napier, C. J. (2011). Does accounting history matter? Accounting History, 16(4), 389-402. https://doi.org/10.1177/1032373211417993

Hopwood, A. (2000). Understanding financial accounting practice" Accounting, Organizations and Society, 25(8), 763-766. https://doi.org/10.1016/s0361-3682(00)00021-0

Hopwood, A., \& Miller, P. (1994). Accounting as social and institutional practice. Cambridge: Cambridge University Press.

Hoskin, K. W., \& Macve, R. (2000). Knowing more as knowing less? Alternative histories of cost and management accounting in the US and the UK. The Accounting Historians Journal, 27(1), 91-149. https://doi.org/10.2308/0148- 4184.27.1.91

Hoskin, K.W., and Macve, R. (1986). Accounting and the examination: a genealogy of disciplinary power. Accounting Organizations and Society, 11(2), 105-136. https://doi.org/10.1016/0361-3682(86)90027-9

Kaye, J. (2000). Economy and Nature in the Fourteenth Century: Money, Market Exchange and the Emergence of Scientific Thought. Cambridge: CUP.

Kelly, P. (2000). Youth as an Artefact of Expertise: Problematizing the Practice of Youth Studies in an Age of Uncertainty. Journal of Youth Studies, 3(3), 301-315. https://doi.org/10.1080/713684381

Lai, A., Leoni, G., \& Stacchezzini, R. (2012). Governmentality rationales and calculative devices: The rejection of 
a seventeenth-century territorial barter proposed by the King of Spain. Accounting History, 17(3-4), 369-392. https://doi.org/10.1177/1032373212443226

Latour, B. (1987). Science in action. How to follow scientists and engineers through Society. Cambridge: Harvard University Press

Madonna, S., Maran, L., \& Cestari, G. (2014). The 1771 and 1824 reforms of the University of Ferrara: A Foucauldian analysis of papal interests. Accounting History, 19(4), 507-532. https://doi.org/10.1177/1032373214552317

Maran, L., Bracci, E., \& Funnell, W. (2016). Accounting and the management of power: Napoleon's occupation of the commune of Ferrara (1796-1799). Critical Perspectives on Accounting, 34, 60-78. https://doi.org/10.1016/j.cpa.2015.10.008

Martini, A. (1883). Manuale di metrologia, ossia misure, pesi e monete in uso attualmente e anticamente presso tutti i popoli. Torino: Loescher.

McKinlay, A., \& Pezet, E. (2010). Accounting for Foucault. Critical Perspectives on Accounting, 21(6), 486-495. https://doi.org/10.1016/j.cpa.2009.08.006

Menning, C. B. (1993). Charity and State in late Renaissance Italy: the Monte di Pieta of Florence. New York: Cornell University Press.

Miller, P. (1994). Accounting as a Social and Institutional Practice: An Introduction. In Hopwood, A. G., and Miller, P. (Eds.), Accounting as Social and Institutional Practice. Cambridge: University Press.

Miller, P., \& Napier, C. J. (1993). Genealogies of calculations. Accounting, Organizations and Society, 18(7/8), 631-647. https://doi.org/10.1016/0361-3682(93)90047-a

Miller, P., \& O'Leary, T. (1987). Accounting and the construction of the governable person. Accounting, Organizations and Society, 12(3), 235-265. https://doi.org/10.1016/0361-3682(87)90039-0

Miller, P., \& Rose, N. (1990). Governing economic life. Economy and Society, 19(1), 1-31. https://doi.org/10.1080/03085149000000001

Montanari, D. (1999). Monti di pietà e presenza ebraica in Italia: secoli 15-18. Roma: Bulzoni.

Muzzarelli, M. G. (2001). Il denaro e la salvezza. L'invenzione del Monte di Pietà. Bologna: Il Mulino.

Napier, C. J. (2006). Accounts of change: 30 years of historical accounting research. Accounting, Organizations and Society, 31(4/5), 445-507. https://doi.org/10.1016/j.aos.2005.12.004

Neu, D. (2000). "Presents" for the "Indians": land, colonialism and accounting in Canada. Accounting, Organizations and Society, 25(2), 163-184. https://doi.org/10.1016/s0361-3682(99)00030-6

Neu, D., \& Graham, C. (2006). The birth of a nation: accounting and Canada's First Nations, 1860-1900. Accounting, Organizations and Society, 31(1), 47-76. https://doi.org/10.1016/j.aos.2004.10.002

Papi, L., Bigoni, M., Deidda Gagliardo, E., \& Funnell, W. (2018). Accounting for power and resistance: The university of Ferrara under the fascist regime in Italy. Critical Perspectives on Accounting. https://doi.org/10.1016/j.cpa.2018.11.001

Parker, L. D. (1999). Historiography for the New Millennium: Adventures in Accounting and Management. Accounting History, 4(2), 11-42. https://doi.org/10.1177/103237329900400204

Parker, L. D. (2015). Accounting historiography: looking back to the future. Meditari Accountancy Research, 2(23), 142- 157. https://doi.org/10.1108/medar-03-2015-0018

Previts, G. J., Parker, L. D., \& Coffman, E. N. (1990a). Accounting history: Definition and relevance. Abacus, 26(1), 1-16. https://doi.org/10.1111/j.1467-6281.1990.tb00229.x

Previts, G. J., Parker, L. D., \& Coffman, E. N. (1990b). An accounting historiography: Subject matter and methodology. Abacus, 26(2), 136-158. https://doi.org/10.1111/j.1467-6281.1990.tb00250.x

Rose, N., \& Miller, P. (1992). Political power beyond the State: problematics of government. The British Journal of Sociology, 43(2), 73-205. https://doi.org/10.2307/591464

Sargiacomo, M. (2009). Accounting for the "good administration of justice": the Farnese State of Abruzzo in the sixteenth century. Accounting History, 14(3), 235-267. https://doi.org/10.1177/1032373209335290

Sharma, U., Lawrence, S., \& Fowler, C. (2012). New public management and accounting in a Fiji $\begin{array}{lllll}\text { telecommunications } & \text { company. } & \text { Accounting History, } & \text { 17(3-4), } & \text { 331-348. }\end{array}$ 
https://doi.org/10.1177/1032373212443534

Stewart, R. E. (1992). Pluralizing Our Past: Foucault in Accounting History. Accounting, Auditing \& Accountability, 5(2), 57-73. https://doi.org/10.1108/09513579210011862

Tan, E. S. (2002). An Empty Shell? Rethinking the Usury Laws in Medieval Europe. The Journal of Legal History, 23(3), 177-196. https://doi.org/10.1080/01440362308539649

Todeschini, G. (2009). Franciscan Wealth: From Voluntary Poverty to Market Society. NY: Franciscan Institute: Saint Bonaventure University

Todeschini, G. (2016). La banca e il ghetto. Una storia italiana (secoli XIV-XVI). Bari-Roma: Laterza

Troilo, M. (2017). Il Monte di pietà di Ravenna e la risposta alle frodi ottocentesche. In: Righi, L. ed. Storie di frodi. Intacchi, malversazioni e furti nei Monti di pietà e negli istituti caritatevoli tra Medioevo ed Età moderna (pp. 311-326). Bologna: Il Mulino.

Van der Wee, H. (1993). The Low Countries and the Early Modern World. Aldershot. Variorum

Varni, A. (1996). Per diritto di conquista. Napoleone e la spoliazione dei Monti di Pietà di Bologna e Ravenna. Bologna: Il Mulino

Vismara, P. (2004). Oltre l'usura: la Chiesa moderna e il prestito a interesse. Soveria Mannelli: Rubbettino

Wyn, J., \& White, R. (1997). Rethinking Youth. St Leonards: Allen \& Unwin

Zan, L. (2004). Accounting and management discourse in protoindustrial settings: the Venice Arsenal in the turn of the XVI Century. Accounting and Business Research, 32(2), 145-175. https://doi.org/10.1080/00014788.2004.9729958

\section{Notes}

Note 1. Over time, the archive of the Monte of Ravenna has suffered numerous losses. The main loss occurred in 1512 after the sack of Ravenna carried out by the French army in the fight against the Holy League. Another loss occurred in 1636 during the disastrous flooding of the Ronco and Montone rivers. A final major loss occurred in 1866, when 330 volumes were sold by the Monte administration to a junk shop because they were considered useless.

Note 2. Which also updated the rules on pawnbroking, raised the maximum amount of the loan (fixed at 250 lire) and reduced the annual interest rate from 2.5 to 2 percent.

Note 3. The Financial Statement of 1824 is the first one prepared in accordance with the Statutes of 1736 and further revisions.

Note 4. The Apostolic Delegate was the representative of the temporal power of the Pope, as Ravenna after the Restoration became Legation administered by an Apostolic Delegate.

Note 5. The monetary system in use during the Restoration was consistent with that papal, reformed in 1835 and was centered on scudi, 1 scudo is worth 100 baiocchi and 1.000 paoli (Martini 1883: 163).

Note 6. In accordance with Statutes of 1614 and its further revision, the loan will correspond to a fraction (2/3) of the estimated value of the pledge.

Note 7. Within other Monti, fraud of Managers had been severely repressed in particular if the Manager did not belong to the aristocracy but came from the ranks of the professional middle class. In Ferrara, for example, the 'intacco' discovered in the mid-17th century - which involved the Monte's failure - was punished by beheading the employee in charge of its management. A situation similar to that of Ferrara took place in Bologna, whose Monte was repeatedly undermined by figures belonging to the professional middle classes, all exemplarily punished with dismissal, imprisonment and in some cases the death penalty (Fornasari, 2017).

Note 8 . The new Statue was enforced in 1837.

\section{Copyrights}

Copyright for this article is retained by the author(s), with first publication rights granted to the journal.

This is an open-access article distributed under the terms and conditions of the Creative Commons Attribution license (http://creativecommons.org/licenses/by/4.0/). 